\title{
DETERMINATION OF TOURISM ACTIVITIES OF THE WORLD'S BEST TOURISM DESTINATIONS WITH MULTI-CRITERIA DECISION MAKING METHOD
}

\author{
M. Oğuzhan İlban ${ }^{1}$ \\ Mehmet Kaşli ${ }^{2}$ \\ Hasan Hüseyin Yildirim ${ }^{3}$
}

\begin{abstract}
In this study, tourism performance of the 15 countries, the most popular tourist destinations of the World, will be analyzed by TOPSIS method. Four factors are determined to measure tourism activities in the countries. These factors are international tourism expenditures, international tourism receipts, international tourism number of arrivals and international tourism number of departures. Then TOPSIS method will be applied to combine the four different factors and convert them into a single performance score. Later, the countries will be ranked and rated. Tourism activities will be used for grading the performance score of the countries. Thus, valuation of tourism activities in the 15 countries will be held for 6 years, between 2009 and 2014, and the obtained results will be compared with th results of international tourism organizations.
\end{abstract}

Key Words: Tourism Industry, Tourism Activities, Topsis Method.

\section{INTRODUCTION}

International tourism, which has been the third biggest sector after petro chemistry and automotive, has grown rapidly in the last half century. Tourism covers $9.5 \%$ of the world economy today. Of all the investment throughout the world $4.4 \%$ is about tourism. Furthermore, $5.4 \%$ of the world export is based on tourism, which will indicate how important tourism is for the world economy (World Travel and Tourism Council, Access 2014). According to a study made by World Tourism Organization (UNWTO), by 2020 the number of people to go into international tourism will be 1 billion and 400 million and by 2030 the figure is expected to go up to 1 billion 800 million people (UNWTO, access date: 15.06.2014). Figures from UNWTO show that touristic arrivals reach to 1 billion and 87 million people in 2013 from 25 million people in 1950. The size of the trade from these touristic travels in the international arena is $\$ 1$ trillion and 159 billion.

Between 1980 and 1995 the increase in the number of tourists throughout the world was $4.4 \%$ and between 1995 and 2010 the increase was $3.9 \%$ in spite of lots of wars, terrorist activities and global crisis which affected every almost every spot of the world. Tourism was almost the only sector which was not seriously affected from all these factors and in 2013 the number of tourists travelling to other countries went up to 1 billion and 87 million.

The world tourism market has observed significant quality change in recent years. Tourism activities have been diversified, tourism expenditures (per person) have increased rapidly, compared to the figures in the past, new regions have been open to international tourism and traditional regions have all been in a great effort to innovations and new

\footnotetext{
${ }^{1}$ Assoc. Professor, Balikesir University, Burhaniye School of Applied Sciences, Tourism and Hotel Management, Balikesir, Turkey.

${ }^{2}$ Assoc. Professor, Eskişehir Osmangazi University, Tourism Faculty, Eskişehir, Turkey.

${ }^{3}$ Lecturer, Balikesir University, Burhaniye School of Applied Sciences, Banking and Finance, Balikesir, Turkey.
} 
competitions. Many countries have been trying to improve their accessible tourism products and to activate their recreational activities in order to attract the ever changing demand for tourism.

The dispersion of the tourism activities throughout the world indicates that Europe and North America take the biggest share from the global tourism activities. The biggest producers in the world tourism and travel sectors are European Union (EU) countries. The tourism activities towards the developing countries have increased rapidly with the effect of the globalization process. By means of the globalization, minimizing the border formalities between countries, more democratic policies in transportation facilities, quality and prices, harmonization of information and communication technologies to all service sectors including tourism, and publicity and advertisement, the potential tourists have been made informed of the supply sources of many new destinations all over the world. In conclusion, the developing countries have increased their share from the tourism market in the recent years. The 15 countries in this study cover approximately $70 \%$ of the total world tourism activities.

\section{ASSESSMENT CRITERIA OF TOURISM ACTIVITIES}

There are four important parameters in the assessment of tourism for countries. These are international tourism expenditures, international tourism receipts, international inbound tourists and international outbound tourists. The definitions of these assessment values are shortly given below:

International tourism expenditures are expenditures of international outbound visitors in other countries, including payments to foreign carriers for international transport. These expenditures may include those by residents traveling abroad as same-day visitors, except in cases where these are important enough to justify separate classification.

International tourism receipts are expenditures by international inbound visitors, including payments to national carriers for international transport. These receipts include any other prepayment made for goods or services received in the destination country. They also may include receipts from same-day visitors, except when these are important enough to justify separate classification.

International inbound tourists (overnight visitors) are the number of tourists who travel to a country other than that in which they have their usual residence, but outside their usual environment, for a period not exceeding 12 months and whose main purpose in visiting is other than an activity remunerated from within the country visited.

International outbound tourists are the number of departures that people make from their country of usual residence to any other country for any purpose other than a remunerated activity in the country visited.

Each of these assessment criteria is of great significance. International tourism receipts seem to be the only criterion to assess tourism incomes to the economy of that country but this is not the case. The number of inbound tourists to a country, for example, is also very important in the advertisement of that country and it will lead to attract more tourists in the future. The expenditures as a result of tourism activities are not only about development levels of the countries but will also give important clues about the frequency of their citizens' participation into tourism activities. On the other hand, these expenditures are also very important assessment criteria to improve the concepts such as customer satisfaction and quality service, which have been used as data in the scope of this study. To sum up, all these factors are significant criteria to assess the tourism activities in a country. 
The study will approach all these criteria equally in the assessment of tourism activities and the tourism performances of the 15 countries, which have attractive destinations in the world scale, will be assessed accordingly.

\section{LITERATURE REVIEW}

Charnes, Cooper \& Rhodes (1978) have taken attention to the importance of different calculation techniques of financial assessment of companies. Deng, Yeh\& Willis (2000) have found out that TOPSIS method is a simple and efficient way to measure and evaluate the internal performance of companies using financial rates as the financial rates used in China in the assessment of companies provide meaningful and helpful data about countries and play an important role in the decision-making process. In their study which aimed to examine the performance of airline companies, Feng \& Wang (2000) have employed the TOPSIS method by using a total of 22 variables as transportation and financial indicators of 5 Taiwanese airline companies and have concluded that these indicators are more affective in the assessment of these companies.

In their study about the selection of the best offer in the bids they make in their manufacturing company, Li\& Qin-Sheng (2006) have used the TOPSIS method to find out the best tender offer from the 4 competing companies for some electronic devices considering 12 indicators. Shih, Shyur \& Lee (2007) have also used the TOPSIS method in the personnel selection of human resources department of a local chemistry company and have proved that the method is a strong one.

LUO, W. B., WANG, Y. J., WU, Y. Z., \& WU, Z. B. (2008) make a study of coordination between urban tourism and urban development in Hangzhou by applying the method of TOPSIS.Based on the in-depth analysis of the present literature on urban tourism, the paper sets up the coordinative evaluation index system of urban tourism and urban development,calculates the coordinative index in Hangzhou and determines the rank of coordinative state. Study result indicates that the coordinative index between urban tourism and urban development increases with each passing year.As time goes by, the coordinative index value gradually approaches ideal optimum,which was 0.8631 in 2005. With the maturity of urbanization and tourism development,coordinative state gradually becomes optimized.The coordinative state in Hangzhou has turned from relative non-coordination in 2001 to high coordination in 2005.

Eleren \& Karagül (2008) studied on the evaluation of the performance of Turkish economy and benefitted from 7 basic indicators between the years 1986 and 2006 and they found in this study that 1986 was the year with the best economic performance and 1999 was the worst using a single performance point for each year by means of the TOPSIS method.

Karimi, Yusop, \& Law (2010) study examines the location decision for foreign direct investment in ASEAN countries using TOPSIS approach, which provides a relatively simple tool for this strategic decision making problem. By using TOPSIS method, the capacity and attraction of ASEAN countries is evaluated and given final rank for period 2000-2005. Within the model, ten indicators are defined as determinants of FDI inflows. The empirical results indicate that Singapore is the most attractive for investment among ASEAN countries while ranking of some countries have changed during these years.

Demireli (2010) tried to determine the performance of the state-owned banks in Turkey with the help of the TOPSIS method. In conclusion, he discovered that the banks 
which have a nationwide operation network were influenced by the regional and global crises between 2001 and 2007; their performance points have fluctuated continually based on international data and banking sector could record any striking improvement in the given period.

Yükçü \& Atağan (2010) tried to measure which company show the best performance by the help of the TOPSIS method using the performance indicators of three companies in the sector and under the same holding. As a result they arranged the order of these three companies of the holding after they made the analysis of the performance of the companies. They concluded that the TOPSIS method gives an opportunity to the decision maker to make more objective evaluation combining different evaluation options into a single criterion.

Zhang, H.,\& Zhang, Y. (2010) The regional competitiveness of tourism resources of 16 cities in the Yangtze River Delta was studied.The analysis results indicate that there is much difference among the 16 cities in tourism resources competitiveness.Suzhou and Hangzhou are the strongest competitive,however,Taizhou and Nantong are the weakest.The conclusion indicates that the weighted TOPSIS method could be applied to the comparative analysis on regional competitiveness of tourism resources, and can reduce the subjective influence and improve the reliability of evaluation results.

Mangir \& Erdogan (2011) aimed to analyze determinants of the financial crisis and recession in the world. In particular, they focused on the following countries where effects of the global financial crisis were severely experienced by using the Topsis method: Italy, Greece, Spanish, Portugal, Ireland and Turkey. The evaluation criteria and sub-criteria used to evaluate the macroeconomic performance are defined as follows: Economic Growth (EG), Inflation rate (IR), Unemployment Rate (UR), Current Account Balance $(\mathrm{CAB})$, Budget Balance rate $(\mathrm{BB})$. In conclusion they find that all countries were affected by the crisis in 2008 but Turkey was the country with the least impact.

Shamai, A.,\& Mosivand, J. (2011) study the factors attracting tourists to a destination and to determine the hierarchy of towns in Isfahan (Iran) based on these factors. The factors assessed for each town include: hotels, motels, suburban units, restaurants, tour and travel agencies, travel service offices, transportation companies, art galleries and cultural exhibitions, public parks, a number of public transport systems, special tourism areas, and capitalization opportunities. TOPSIS model has been used for making a hierarchy of tourism substructures, while the AHP approach was used for the final ranking. Isfahan ranked first, with Kashan and Shahin Shahr in second and third place, respectively. Suggestions for tourism development are presented.

Mohamad, D.,\& Jamil, R. M. (2012) study an evaluation of the critical factors influencing local tourists choice of destinations in Kedah anddetermination of the tourists preference for destinations with respect to these factors using Fuzzy Hierarchical TOPSIS (FHTOPSIS) method. This study focuses on the internal factors that motivate tourists to choose their preference of destination. The result shows the purpose of visiting friends and relatives is the most important factors that motivate their visit to Kedah, while novelty seeking is the least motivating factors influencing the choice of destinations. The best destination to be selected among five destinations under consideration in this study is Langkawi, followed by Alor Setar, Sedim River, Bujang Valley and Bukit Kayu Hitam. This study can assist relevant authorities and travel agencies to plan and promote the places of attraction in Kedah with effective marketing strategies besides assisting tourists to decide where to go to main attractions in Kedah. 
Huang, J. H.,\& Peng, K. H. (2012) analyze the Tourism Destination Competitiveness (TDC) of nine Asian countries: China, Hong Kong, Japan, Korea, Malaysia, Singapore, Taiwan, Thailand and the Philippines. The study was conducted in 2009 using 6 criteria and 15 indices. The results in 2009, the Asian countries were ranked from most to least competitive as follows: China, Japan, Hong Kong, Malaysia, Thailand, Singapore, Taiwan, Korea and the Philippines.

Supçiler \& Çapraz (2011) have focused on the problem of supplier selection in their study. They have made the most appropriate supplier selection by means of the TOPSIS method, the multi-criteria decision making method. They selected the best supplier with the highest score among the present suppliers, the one which will give the maximum benefit to the company. The main criteria they used in the selection of the supplier were quality, cost, delivery and service.

Uyguntürk \& Korkmaz (2012) make the analysis of financial performance of the 13 main metal industry companies in Borsa Istanbul using the financial tables of the companies from 2006 to 2010 by means of the TOPSIS method. By TOPSIS they convert general company performance of the companies into a single point by means of the TOPSIS method and used this point in order to rankthe companies from the best to the worst. They find that the performance points of the companies in the metal sector generally change in analysis periods.

Urfalığlu \& Genç (2013) use the TOPSIS method to determine the economic situation of Turkey in the EU process. The decision criteria in the study are gross national product per capita, the rate of growth, export, import, employment and inflation, which are applied to 27 full member countries of EU and 5 candidate countries of the EU, Turkey, Macedonia, Iceland, Croatia and Montenegro. They compare the results they find through the TOPSIS method with other decision making methods and find very close findings to other multi criteria decision making methods.

\section{RESEARCH METHOD}

A general overviewto all tourism activities will show that there are 15 important destinations in the world. These destinations cover $70 \%$ of the global tourism activities.

Four main factors are included in the analysis between 2009 and 2014to be able to see the comparative performance of the 15 important destinations. The information in the period of these 6 years about tourism expenditures, tourism receipts, inbound tourists and outbound tourists was taken from the annual UNWTO, Tourism Highlights and World Bank Tourism Data. The information and codes of the 15 countries to be used as important destinations for the analysis are given in Tab. 1. 
Tab. 1. The countries of the study

\begin{tabular}{|l|l|l|}
\hline Number & Country Code & Name \\
\hline 1 & AUT & Austria \\
\hline 2 & CAN & Canada \\
\hline 3 & CHN & China \\
\hline 4 & DEU & Germany \\
\hline 5 & ESP & Spain \\
\hline 6 & FRA & France \\
\hline 7 & GBR & United Kingdom \\
\hline 8 & GRC & Greece \\
\hline 9 & HUN & Hungary \\
\hline 10 & ITA & Italy \\
\hline 11 & MEX & Mexico \\
\hline 12 & POL & Poland \\
\hline 13 & RUS & Russian Federation \\
\hline 14 & TUR & Turkey \\
\hline 15 & USA & The United States \\
\hline
\end{tabular}

The analysis of the study consists of two steps. In the first one, four tourism data are determined to define the tourism performance of the destinations and then the data for the period from 2009 to 2014 are compiled for each of the 15 countries respectively. In the second step the TOPSIS, which is the commonest decision making method used in multi criteria decision making processes, converts the general tourism performance of the countries into a single point. In the end, the destination rating is completed and the countries are ordered according to the points they own from the biggest to the smallest.

Tab. 2. shows a list of the codes of the tourism activities used in the study.

Tab. 2. Tourism Activities and Codes

\begin{tabular}{|l|l|l|}
\hline NO & KOD & RATES \\
\hline $\mathbf{1}$ & EXP & International tourism expenditures $(\$)$ \\
\hline $\mathbf{2}$ & REC & International tourism receipts $(\$)$ \\
\hline $\mathbf{3}$ & ARR & International tourism, number of arrivals \\
\hline $\mathbf{4}$ & DEP & International tourism, number of departures \\
\hline
\end{tabular}

In general, only the top 10 countries are given for each criterion in the rating of each criterion. The study was applied in the years from 2009 to 2014 and the top 10 countries are not the same for the six years. For this reason, considering the changing countries, the four assessment criteria are employed for the 15 countries with regard to the result in the mentioned years.

With the TOPSIS, one of the most common decision making methods, the performance of 15 most popular countries of the world is analyzed and their tourism activities are rated in this study. These counties cover $70 \%$ of all tourism activities. 


\section{TOPSIS METHOD}

Decision problem involves the process of determining the best option among the most appropriate options. There are a wide variety of purposes such as TOPSIS, ELECTRA, AHP, Fuzzy AHP, and Fuzzy TOPSIS for people who need to make a decision in the face of multivariate decision-making problems. In recent years, a method of deciding a multi-purpose one of the commonly used methods TOPSIS method based on multiple criteria evaluation and decision-makers are used as a successful method.

TOPSIS (technique for order preference by similarity to an ideal solution) method is presented in Chen and Hwang, with reference to Hwang and Yoon. TOPSIS is a multiple criteria method to identify solutions from a finite set of alternatives. The basic principle is that the chosen alternative should have the shortest distance from the positive ideal solution and the farthest distance from the negative ideal solution. The procedure of TOPSIS can be expressed in a series of steps:

\section{Step 1: Creating a Decision Matrix (A)}

Decisions of the listed advantages of line matrix takes place the desired decision points. At the same time, the decision matrix is located in the columns of assessment factors to be used in decision making. The initial matrix is a matrix formed by decision makers. The decision matrix is shown as follows:

$$
A_{i j}=\left[\begin{array}{cccc}
a_{11} & a_{12} & \ldots & a_{1 n} \\
a_{21} & a_{22} & \ldots & a_{2 n} \\
\cdot & & & \cdot \\
\cdot & & & \cdot \\
\cdot & & & \cdot \\
a_{m 1} & a_{m 2} & \ldots & a_{m n}
\end{array}\right]
$$

"m" is the number of decision points in the $A_{i j}$ matrix and "n" gives the number of the evaluation factors.

\section{Step 2: Creating a Standard Decision Matrix (R)}

$$
r_{i j}=x_{i j} \sqrt{\sum_{i-1}^{m} x_{i j}^{2}} \mathrm{i}=1,2, \ldots, \mathrm{m} \text { and } \mathrm{j}=1,2, \ldots, \text { n.(1) }
$$

Matrix R is obtained as shown on $R_{i j}=\left[\begin{array}{cccc}r_{11} & r_{12} & \ldots & r_{1 n} \\ r_{21} & r_{22} & \ldots & r_{2 n} \\ \cdot & & & \cdot \\ \cdot & & & \cdot \\ \cdot & & & \cdot \\ r_{m 1} & r_{m 2} & \ldots & r_{m n}\end{array}\right]$ 
Step 3: Calculate the weighted normalized decision matrix (V)

The weighted normalized value $v_{i j}$ is calculated asfollows:

$$
v_{i j}=r_{i j} \times w_{j} \mathrm{i}=1,2, \ldots, \mathrm{m} \text { and } \mathrm{j}=1,2, \ldots, \mathrm{n}
$$

where $\mathcal{W}_{j}$ is the weight of the $j^{\text {th }}$ criterion or attribute and $\sum_{j=1}^{n} \mathcal{W}_{j}=1$.

$$
V_{i j}=\left[\begin{array}{cccc}
w_{1} r_{11} & w_{2} r_{12} & \ldots & w_{n} r_{1 n} \\
w_{1} r_{21} & w_{2} r_{22} & \ldots & w_{n} r_{2 n} \\
\cdot & & & \cdot \\
\cdot & & & \cdot \\
\cdot & & & \cdot \\
w_{1} r_{m 1} & w_{2} r_{m 2} & \ldots & w_{n} r_{m n}
\end{array}\right]
$$

Step 4: Determine the ideal ( $\left.A^{*}\right)$ and negative ideal $\left(A^{-}\right)$solutions.

$$
\begin{gathered}
A^{*}=\left\{\left(\max _{i} v_{i j} \mid j \in C_{b}\right),\left(\min _{i} v_{i j} \mid j \in C_{c}\right)\right\}=\left\{v_{j}^{*} \mid j=1,2, \ldots, m\right\} \\
A^{-}=\left\{\left(\min _{i} v_{i j} \mid j \in C_{b}\right),\left(\max _{i} v_{i j} \mid j \in C_{c}\right)\right\}=\left\{v_{j}^{-} \mid j=1,2, \ldots, m\right\}
\end{gathered}
$$

Step 5: Calculate the separation measures using the m-dimensional Euclidean distance.

The separation measures of each alternative from the positive ideal solution and the negative ideal solution, respectively, are as follows:

$$
\begin{aligned}
& S_{i}^{*}=\sqrt{\sum_{j=1}^{m}\left(v_{i j}-v_{j}^{*}\right)^{2}, j=1,2, \ldots, m \text { (4) }} \\
& S_{i}^{-}=\sqrt{\sum_{j=1}^{m}\left(v_{i j}-v_{j}^{-}\right)^{2}, j=1,2, \ldots, m \text { (5) }}
\end{aligned}
$$

Step 6: Calculate the relative closeness to the ideal solution.

The relative closeness of the alternative $A_{i}$ with respect to $A^{*}$ is defined asfollows: 


$$
C_{i}^{*}=\frac{S_{i}^{-}}{S_{i}^{*}+S_{i}^{-}}, i=1,2, \ldots, m(\mathbf{6})
$$

Rank the preference order; Then found $C_{i}^{*}$ values of the order of magnitude sequenced in order of importance is determined by the decision point.

\section{FINDINGS OF THE STUDY}

Of all the countries with tourism destinations, 15 countries are put into the scope of analysis in this study. The codes of these 15 countries are AUT, CAN, CHN, DEU, ESP, FRA, GBR, GRC, HUN, ITA, MEX, POL, RUS, TUR and USA. To see the destination performance of these countries, the tourism activity criterion is used for the years from 2009 to 2014.

The study is composed of two steps. In the first step of the analysis, 4 tourism data are determined to define the tourism performance of the countries. Later, the data for the 15 countries are calculated one by one for the years from 2009 to 2014 according to these criteria. In the second step, the four factors chosen to determine the performance of these attractive tourism destinations are used to calculate a single score for the tourism performance of each country by means of TOPSIS. Then, the countries are put into order according to this score and their rating is completed. Calculating the general score of each country one by one for the period of 2009-2014, the countries are rated for the study. The excel program is used to apply the TOPSIS method.

The first step is to make the Decision Matrix (A) in the application of the TOPSIS method. In the lines of the Decision Matrix read decision points intended to order the superiorities of the countries, and in the columns are evaluation criteria to be used for decision making. Matrix A is the beginning matrix for the decision maker. The matrix for 2009 is given as a sample. Not all other matrixes will be given here separately because all include the same application.

Step 1: Forming Matrix A: There are 15 decision points (alternatives / destinations) and 4 assessment factors (criteria / tourism evaluation criteria) in the study. Firstly a standard decision making matrix is made with dimensions (15X 4) for the TOPSIS method. According to this matrix, the decision matrix of the 15 countries is given in Tab. 3. 
Tab. 3. Decision Making Matrix for 2009

\begin{tabular}{|l|l|r|r|r|r|}
\hline No. & Country Code & \multicolumn{1}{l|}{ EXP $(\$)$} & \multicolumn{1}{l|}{ REC $\mathbf{( \$ )}$} & \multicolumn{1}{l|}{ ARR } & \multicolumn{1}{l|}{ DEP } \\
\hline $\mathbf{1}$ & AUT & 12.767 .000 .000 & 21.220 .000 .000 & 21.355 .000 & 10.121 .000 \\
\hline $\mathbf{2}$ & CAN & 30.065 .000 .000 & 15.568 .000 .000 & 15.737 .000 & 26.204 .000 \\
\hline $\mathbf{3}$ & CHN & 47.108 .000 .000 & 42.632 .000 .000 & 50.875 .000 & 47.656 .000 \\
\hline $\mathbf{4}$ & DEU & 92.829 .000 .000 & 47.462 .000 .000 & 24.220 .000 & 72.300 .000 \\
\hline $\mathbf{5}$ & ESP & 22.787 .000 .000 & 59.743 .000 .000 & 52.178 .000 & 12.017 .000 \\
\hline $\mathbf{6}$ & FRA & 45.806 .000 .000 & 58.857 .000 .000 & 76.764 .000 & 25.140 .000 \\
\hline $\mathbf{7}$ & GBR & 61.133 .000 .000 & 38.564 .000 .000 & 28.199 .000 & 58.614 .000 \\
\hline $\mathbf{8}$ & GRC & 3.401 .000 .000 & 14.796 .000 .000 & 14.915 .000 & 3.835 .000 \\
\hline $\mathbf{9}$ & HUN & 3.251 .000 .000 & 7.013 .000 .000 & 9.058 .000 & 16.640 .000 \\
\hline $\mathbf{1 0}$ & ITA & 34.399 .000 .000 & 41.938 .000 .000 & 43.239 .000 & 29.060 .000 \\
\hline $\mathbf{1 1}$ & MEX & 8.737 .000 .000 & 12.542 .000 .000 & 22.346 .000 & 14.104 .000 \\
\hline $\mathbf{1 2}$ & POL & 7.888 .000 .000 & 9.843 .000 .000 & 11.890 .000 & 39.270 .000 \\
\hline $\mathbf{1 3}$ & RUS & 23.785 .000 .000 & 12.369 .000 .000 & 21.339 .000 & 34.276 .000 \\
\hline $\mathbf{1 4}$ & TUR & 5.061 .000 .000 & 26.331 .000 .000 & 30.187 .000 & 5.561 .000 \\
\hline $\mathbf{1 5}$ & USA & 102.953 .000 .000 & 146.002 .000 .000 & 55.103 .000 & 62.051 .000 \\
\hline
\end{tabular}

Step 2: Forming the Standard Decision Matrix $(\boldsymbol{R})$ : The normalized decision matrix is calculated by using the elements of Matrix A and the equation number 1.

Tab. 4. Standard Decision Matrix for 2009

\begin{tabular}{|l|l|l|l|l|l|}
\hline Number & Country Code & EXP & REC & ARR & DEP \\
\hline $\mathbf{1}$ & AUT & 0,07275 & 0,1092 & 0,1491 & 0,0708 \\
\hline $\mathbf{2}$ & CAN & 0,17133 & 0,0800 & 0,1098 & 0,1833 \\
\hline $\mathbf{3}$ & CHN & 0,26845 & 0,2180 & 0,3552 & 0,3333 \\
\hline $\mathbf{4}$ & DEU & 0,52900 & 0,2425 & 0,1691 & 0,5057 \\
\hline $\mathbf{5}$ & ESP & 0,12985 & 0,3041 & 0,3643 & 0,0840 \\
\hline $\mathbf{6}$ & FRA & 0,26103 & 0,2993 & 0,5360 & 0,1758 \\
\hline $\mathbf{7}$ & GBR & 0,34837 & 0,1951 & 0,1969 & 0,4100 \\
\hline $\mathbf{8}$ & GRC & 0,01938 & 0,0763 & 0,1041 & 0,0268 \\
\hline $\mathbf{9}$ & HUN & 0,01852 & 0,0362 & 0,0632 & 0,1164 \\
\hline $\mathbf{1 0}$ & ITA & 0,19603 & 0,2148 & 0,3019 & 0,2032 \\
\hline $\mathbf{1 1}$ & MEX & 0,04978 & 0,0647 & 0,1560 & 0,0986 \\
\hline $\mathbf{1 2}$ & POL & 0,04495 & 0,0508 & 0,0830 & 0,2747 \\
\hline $\mathbf{1 3}$ & RUS & 0,13554 & 0,0638 & 0,1490 & 0,2397 \\
\hline $\mathbf{1 4}$ & TUR & 0,02884 & 0,1354 & 0,2108 & 0,0389 \\
\hline $\mathbf{1 5}$ & USA & 0,58669 & 0,7270 & 0,3847 & 0,4340 \\
\hline
\end{tabular}

Step 3: Forming Weighted Standard Decision Matrix ( $V$ ): In this step, first weight rates $\left(W_{i}\right)$ are calculated for assessment factors. Later the standard values are calculated by multiplying normalized standard values, calculated above, with $\left(W_{i}\right)$ values to find out weighted standard values. The assessment factors are weighted equally in 
decision making for 2009. When all factors are valued 1, equally for dispersion, the weighted assessment factor will be $25 \%$ for each factor. For the weighted standard decision matrix to be formed, the columns of Matrix $\mathrm{V}$ is calculated by multiplication of the values in the columns of Matrix $\mathrm{R}$ with the weight values of assessment factors (here all take $25 \%$ ). In the Tab. 5 is given the weighted standard decision matrix of the countries together with the solution sets ideal $A^{*}$ and ideal $A^{*}$.

Tab. 5. Weighted Standard Decision Matrix for 2009

\begin{tabular}{|l|l|l|l|l|l|}
\hline Number & Country Code & EXP & REC & ARR & DEP \\
\hline $\mathbf{1}$ & AUT & 0,0181 & 0,0273 & 0,0372 & 0,0177 \\
\hline $\mathbf{2}$ & CAN & 0,0428 & 0,0200 & 0,0274 & 0,0458 \\
\hline $\mathbf{3}$ & CHN & 0,0671 & 0,0545 & 0,0888 & 0,0833 \\
\hline $\mathbf{4}$ & DEU & 0,1322 & 0,0606 & 0,0422 & 0,1264 \\
\hline $\mathbf{5}$ & ESP & 0,0324 & 0,0760 & 0,0910 & 0,0210 \\
\hline $\mathbf{6}$ & FRA & 0,0652 & 0,0748 & 0,1340 & 0,0439 \\
\hline $\mathbf{7}$ & GBR & 0,0870 & 0,0487 & 0,0492 & 0,1025 \\
\hline $\mathbf{8}$ & GRC & 0,0048 & 0,0190 & 0,0260 & 0,0067 \\
\hline $\mathbf{9}$ & HUN & 0,0046 & 0,0090 & 0,0158 & 0,0291 \\
\hline $\mathbf{1 0}$ & ITA & 0,0490 & 0,0537 & 0,0754 & 0,0508 \\
\hline $\mathbf{1 1}$ & MEX & 0,0124 & 0,0161 & 0,0390 & 0,0246 \\
\hline $\mathbf{1 2}$ & POL & 0,0112 & 0,0127 & 0,0207 & 0,0686 \\
\hline $\mathbf{1 3}$ & RUS & 0,0338 & 0,0159 & 0,0372 & 0,0599 \\
\hline $\mathbf{1 4}$ & TUR & 0,0072 & 0,0338 & 0,0527 & 0,0097 \\
\hline $\mathbf{1 5}$ & USA & 0,1466 & 0,1817 & 0,0961 & 0,1085 \\
\hline \multicolumn{5}{|l|}{} \\
\cline { 2 - 6 } & MAX $\left(\boldsymbol{A}^{*}\right)$ & 0,1466 & 0,1817 & 0,1340 & 0,1264 \\
\hline MíN $\left(\boldsymbol{A}^{-}\right)$ & 0,0046 & 0,0090 & 0,0158 & 0,0067 \\
\hline
\end{tabular}

Step 4: Forming the Analysis of Ideal ( $\left.A^{*}\right)$ and Negative Ideal ( $A^{-}$):In this step solution sets of ideal $A^{*}$ and negative ideal $A^{-}$are formed. For the set $A^{*}$ the biggest value in each column of the Matrix V and the smallest for the set $A^{-}$in the same column are selected and sets are arranged according to appropriateness of the criteria to the goal.

$$
\begin{gathered}
A^{*}=\left\{\left(\max _{i} v_{i j} \mid j \in J\right),\left(\min _{i} v_{i j} \mid j \in J^{\prime}\right\}\right. \\
A^{-}=\left\{\left(\min _{i} v_{i j} \mid j \in J\right),\left(\max _{i} v_{i j} \mid j \in J^{\prime}\right\}\right.
\end{gathered}
$$

According to the formula;

$$
\begin{aligned}
& A^{*}=\{0,1466 ; 0,1817 ; 0,1340 ; 0,1264\} \\
& A^{-}=\{0,0046 ; 0,0090 ; 0,0158 ; 0,0067\}
\end{aligned}
$$


Step 5: Calculation of the Selection Criteria: The space between alternatives are found by means of the Euclidean distance with the dimension $\mathrm{n}$. The distance of each alternative from the positive ideal solution $\left(S_{i}^{*}\right)$ and from the negative ideal solution $\left(S_{i}^{-}\right)$ is calculated with formulae (4) and (5).

$$
\begin{aligned}
& S_{i}^{*}=\left\{\begin{array}{c}
0,2480 ; 0,2340 ; 0,1625 ; 0,1526 ; 0,1928 ; 0,1576 ; 0,1702 ; 0,2693 ; 0,2710 ; \\
0,1873 ; 0,2545 ; 0,2511 ; 0,2323 ; 0,2481 ; 0,0418
\end{array}\right\} \\
& S_{i}^{-}=\left\{\begin{array}{c}
0,0331 ; 0,0569 ; 0,1310 ; 0,1843 ; 0,1055 ; 0,1528 ; 0,1366 ; 0,0143 ; 0,0223 ; \\
0,0973 ; 0,0311 ; 0,0626 ; 0,0647 ; 0,0446 ; 0,2585
\end{array}\right\}
\end{aligned}
$$

Step 6: Calculation of Proximity According to Ideal Solution: In the calculation of relative proximity $\left(C_{i}^{*}\right)$ of ideal solution to each decision point, ideal and negative ideal distinction scores are used. The calculation of proximity value relative to ideal solution is indicated in Formula (6).

$C_{i}^{*}$ is normally valued between $0 \leq C_{i}^{*} \leq 1$ for 2009 and the equation as $C_{i}^{*}=1$ indicates proximity to ideal solution and $C_{i}^{*}=0$ indicates absolute proximity to negative ideal solution. Tab. 6 shows the calculation of relative proximity of the countries to ideal solution for the year 2009 .

Tab. 6. Relative Proximity Values to Ideal Solution in the year 2009

\begin{tabular}{|l|l|}
\hline Country Code & $\mathbf{C}^{*}$ \\
\hline AUT & $0,0331 /(0,0331+0,2480)=\mathbf{0 , 1 1 7 8}$ \\
\hline CAN & $0,0569 /(0,0569+0,2340)=\mathbf{0 , 1 9 5 0}$ \\
\hline CHN & $0,1310 /(0,1310+0,1625)=\mathbf{0 , 4 4 6 3}$ \\
\hline DEU & $0,1843 /(0,1843+0,1526)=\mathbf{0 , 5 4 7 0}$ \\
\hline ESP & $0,1055 /(0,1055+0,1928)=\mathbf{0 , 3 5 3 6}$ \\
\hline FRA & $0,1528 /(0,1528+0,1576)=\mathbf{0 , 4 9 2 1}$ \\
\hline GBR & $0,1366 /(0,1366+0,1702)=\mathbf{0 , 4 4 5 2}$ \\
\hline GRC & $0,0143 /(0,0143+0,2693)=\mathbf{0 , 0 5 0 4}$ \\
\hline HUN & $0,0223 /(0,0223+0,2710)=\mathbf{0 , 0 7 6 3}$ \\
\hline ITA & $0,0973 /(0,0973+0,1873)=\mathbf{0 , 3 4 1 8}$ \\
\hline MEX & $0,0311 /(0,0311+0,2545)=\mathbf{0 , 1 0 9 1}$ \\
\hline POL & $0,0626 /(0,0626+0,2511)=\mathbf{0 , 1 9 9 5}$ \\
\hline RUS & $0,0647 /(0,0647+0,2323)=\mathbf{0 , 2 1 8 0}$ \\
\hline TUR & $0,0446 /(0,0446+0,2481)=\mathbf{0 , 1 5 2 4}$ \\
\hline USA & $0,2585 /(0,2585+0,0418)=\mathbf{0 , 8 6 0 6}$ \\
\hline
\end{tabular}

In this step the $C_{i}^{*}$ values are arranged according to how big they are and the order of decision points (alternatives) is made. The scores are arranged from the biggest to the smallest to indicate which country take more attraction. 
Tab. 7. Scores and Order of Destinations

\begin{tabular}{|l|l|l|}
\hline \multicolumn{3}{|c|}{2009} \\
\hline Order & Country Code & Scores \\
\hline 1 & USA & 0,860671 \\
\hline 2 & DEU & 0,547057 \\
\hline 3 & FRA & 0,492196 \\
\hline 4 & CHN & 0,446348 \\
\hline 5 & GBR & 0,445202 \\
\hline 6 & ESP & 0,353655 \\
\hline 7 & ITA & 0,34189 \\
\hline 8 & RUS & 0,218031 \\
\hline 9 & POL & 0,199582 \\
\hline 10 & CAN & 0,195728 \\
\hline 11 & TUR & 0,152433 \\
\hline 12 & AUT & 0,117846 \\
\hline 13 & MEX & 0,109127 \\
\hline 14 & HUN & 0,076328 \\
\hline 15 & GRC & 0,050471 \\
\hline
\end{tabular}

The order of scores for each destination is given in Tab. 7, which also points out that the country with code USA ( The United States of America) realizes the best performance and the country with GRC (Greece) the worst performance, based on the four criteria chosen among the assessment factors from the destination performances of the year 2009 . According to Tab. 7, the order of the destinations according to their performance in 2009 is as follows: USA(1), DEU(2), FRA(3), $\mathrm{CHN}(4), \operatorname{GBR}(5), \operatorname{ESP}(6), \operatorname{ITA}(7), \operatorname{RUS}(8)$, POL(9), CAN(10), TUR(11), AUT(12), MEX(13), HUN(14), GRC (15).

The analysis for the year 2009 is repeated for 2010, 2011, 2012, 2013, 2014 respectively and the obtained findings are given in Tab. 8. The table (8) gives the results of the ratings of the 15 destinations for each year separately calculating the tourism activity performance scores of each country from 2009 to 2014. 
Tab. 8. The Performance of 15 Important Destinations of the World from 2009 to 2014.

\begin{tabular}{|l|l|l|}
\hline 2009 & \multicolumn{2}{|l|}{} \\
\hline Rating & Codes & Scores \\
\hline 1 & USA & 0,8607 \\
\hline 2 & DEU & 0,5471 \\
\hline 3 & FRA & 0,4922 \\
\hline 4 & CHN & 0,4463 \\
\hline 5 & GBR & 0,4452 \\
\hline 6 & ESP & 0,3537 \\
\hline 7 & ITA & 0,3419 \\
\hline 8 & RUS & 0,2180 \\
\hline 9 & POL & 0,1996 \\
\hline 10 & CAN & 0,1957 \\
\hline 11 & TUR & 0,1524 \\
\hline 12 & AUT & 0,1178 \\
\hline 13 & MEX & 0,1091 \\
\hline 14 & HUN & 0,0763 \\
\hline 15 & GRC & 0,0505 \\
\hline & &
\end{tabular}

\begin{tabular}{|l|l|l|}
\hline 2010 & \multicolumn{3}{|l|}{} \\
\hline Rating & Codes & Scores \\
\hline 1 & USA & 0,8668 \\
\hline 2 & DEU & 0,5293 \\
\hline 3 & CHN & 0,4876 \\
\hline 4 & FRA & 0,4517 \\
\hline 5 & GBR & 0,4106 \\
\hline 6 & ESP & 0,3252 \\
\hline 7 & ITA & 0,3099 \\
\hline 8 & RUS & 0,2374 \\
\hline 9 & CAN & 0,2142 \\
\hline 10 & POL & 0,2028 \\
\hline 11 & TUR & 0,1459 \\
\hline 12 & AUT & 0,1084 \\
\hline 13 & MEX & 0,1053 \\
\hline 14 & HUN & 0,0679 \\
\hline 15 & GRC & 0,0398 \\
\hline & &
\end{tabular}

\begin{tabular}{|l|l|l|}
\hline 2011 & \multicolumn{2}{l|}{} \\
\hline Rating & Codes & Scores \\
\hline 1 & USA & 0,8353 \\
\hline 2 & DEU & 0,5292 \\
\hline 3 & CHN & 0,5219 \\
\hline 4 & FRA & 0,4617 \\
\hline 5 & GBR & 0,3973 \\
\hline 6 & ESP & 0,3296 \\
\hline 7 & ITA & 0,3042 \\
\hline 8 & RUS & 0,2541 \\
\hline 9 & CAN & 0,2111 \\
\hline 10 & POL & 0,1903 \\
\hline 11 & TUR & 0,1529 \\
\hline 12 & AUT & 0,1027 \\
\hline 13 & MEX & 0,0953 \\
\hline 14 & HUN & 0,0611 \\
\hline 15 & GRC & 0,0443 \\
\hline & &
\end{tabular}

\begin{tabular}{|l|l|l|}
\hline \multicolumn{2}{|l|}{012} \\
\hline Rating & Codes & Scores \\
\hline 1 & USA & 0,8614 \\
\hline 2 & CHN & 0,5627 \\
\hline 3 & DEU & 0,4912 \\
\hline 4 & FRA & 0,4351 \\
\hline 5 & GBR & 0,3804 \\
\hline 6 & ESP & 0,3088 \\
\hline 7 & RUS & 0,2835 \\
\hline 8 & ITA & 0,2820 \\
\hline 9 & CAN & 0,2121 \\
\hline 10 & TUR & 0,1542 \\
\hline 11 & AUT & 0,1034 \\
\hline 12 & MEX & 0,0978 \\
\hline 13 & HUN & 0,0590 \\
\hline 14 & POL & 0,0472 \\
\hline 15 & GRC & 0,0368 \\
\hline
\end{tabular}

\begin{tabular}{|l|l|l|}
\hline 2013 & \multicolumn{3}{l|}{} \\
\hline Rating & Codes & Scores \\
\hline 1 & USA & 0,8238 \\
\hline 2 & CHN & 0,5762 \\
\hline 3 & DEU & 0,4979 \\
\hline 4 & FRA & 0,4213 \\
\hline 5 & GBR & 0,3664 \\
\hline 6 & ESP & 0,3083 \\
\hline 7 & RUS & 0,3024 \\
\hline 8 & ITA & 0,2702 \\
\hline 9 & CAN & 0,1758 \\
\hline 10 & TUR & 0,1604 \\
\hline 11 & AUT & 0,0998 \\
\hline 12 & MEX & 0,0960 \\
\hline 13 & HUN & 0,0534 \\
\hline 14 & GRC & 0,0482 \\
\hline 15 & POL & 0,0481 \\
\hline
\end{tabular}

\begin{tabular}{|l|l|l|}
\hline 2014 & \multicolumn{3}{l|}{} \\
\hline Rating & Codes & Scores \\
\hline 1 & USA & 0,7631 \\
\hline 2 & CHN & 0,6287 \\
\hline 3 & DEU & 0,4754 \\
\hline 4 & FRA & 0,3889 \\
\hline 5 & GBR & 0,3485 \\
\hline 6 & ESP & 0,3132 \\
\hline 7 & RUS & 0,2744 \\
\hline 8 & ITA & 0,2617 \\
\hline 9 & CAN & 0,1719 \\
\hline 10 & TUR & 0,1519 \\
\hline 11 & AUT & 0,1189 \\
\hline 12 & MEX & 0,1075 \\
\hline 13 & GRC & 0,0632 \\
\hline 14 & HUN & 0,0519 \\
\hline 15 & POL & 0,0434 \\
\hline
\end{tabular}

\section{CONCLUSION}

15 important destinations are included in the analysis of this study. These are coded as AUT, CAN, CHN, DEU, ESP, FRA, GBR, GRC, HUN, ITA, MEX, POL, RUS, TUR and USA. The activity reports of these countries are used in the analysis of the performance of these countries. The study takes four tourism activities into account as criteria. These are international tourism expenditures, international tourismreceipts, the number of inbound tourists and the number of outbound tourists. 
The analysis of the study is composed of two steps. In the first step, the four tourism data have been selected to define the performance of these tourism destinations and then the data from these 15 countries in the period from 2009 to 2014 are collected. In the second step, these four factors selected for the tourism destinations are converted into a single score to show their performance more clearly by means of the TOPSIS method, one of the most common multi criteria decision making methods. Later, the countries are ordered according to their scores with respect to the criteria and the ratings of the countries are completed. The ratings of the tourism destinations are made by calculating their separate general tourism performance for six years from 2009 till 2014.

The evaluation of each destination is given in three separate tables for 2009-2014. In Tab. 9 is given the destinations the performance of which stays constant through the years, in Tab. 10 is given those whose performance improves through the years and in Tab. 11 is given the destinations whose performance is getting worse.

Tab. 9. The Destinations whose tourism activities stay constant (2009-2014)

\begin{tabular}{|l|c|c|c|c|c|c|}
\cline { 2 - 7 } \multicolumn{1}{c|}{} & $\mathbf{2 0 0 9}$ & $\mathbf{2 0 1 0}$ & $\mathbf{2 0 1 1}$ & $\mathbf{2 0 1 2}$ & $\mathbf{2 0 1 3}$ & $\mathbf{2 0 1 4}$ \\
\hline USA & 1 & 1 & 1 & 1 & 1 & 1 \\
\hline GBR & 5 & 5 & 5 & 5 & 5 & 5 \\
\hline ESP & 6 & 6 & 6 & 6 & 6 & 6 \\
\hline
\end{tabular}

Tab. 9 shows that the United States of America (USA), United Kingdom (GBR) and Spain (ESP) could sustain their tourism activities constantly in the years from 2009 to 2014. According to the analysis made above, these three countries maintain their performance the same through years. They protected their position in tourism activities from 2009 till 2014 in the world competition.

Tab. 10. The destination whose tourism activities improve (2009-2014)

\begin{tabular}{|l|c|c|c|c|c|c|}
\cline { 2 - 7 } \multicolumn{1}{c|}{} & $\mathbf{2 0 0 9}$ & $\mathbf{2 0 1 0}$ & $\mathbf{2 0 1 1}$ & $\mathbf{2 0 1 2}$ & $\mathbf{2 0 1 3}$ & $\mathbf{2 0 1 4}$ \\
\hline CHN & 4 & 3 & 3 & 2 & 2 & 2 \\
\hline RUS & 8 & 8 & 8 & 7 & 7 & 7 \\
\hline CAN & 10 & 9 & 9 & 9 & 9 & 9 \\
\hline TUR & 11 & 11 & 11 & 10 & 10 & 10 \\
\hline AUT & 12 & 12 & 12 & 11 & 11 & 11 \\
\hline MEX & 13 & 13 & 13 & 12 & 12 & 12 \\
\hline HUN & 14 & 14 & 14 & 13 & 13 & 14 \\
\hline GRC & 15 & 15 & 15 & 15 & 14 & 13 \\
\hline
\end{tabular}

Tab. 10 indicates the change or improvement in the position of China $(\mathrm{CHN})$. This destination rose to the second rate from the fourth in the given 6 years. The other countries which improved their place to a higher level are Russian Federation (RUS), Canada (CAN), Turkey (TUR), Austria (AUT), Mexico (MEX) and Hungary (HUN). Greece is another destination which rose to a higher level especially in 2013 and 2014 from the 15 th in the year 2009 Greece went up to 14th in 2013 and 13th in 2014. 
Tab. 11. The destinations whose performance goes worse (2009-2014)

\begin{tabular}{|l|c|c|c|c|c|c|}
\cline { 2 - 7 } \multicolumn{1}{c|}{} & $\mathbf{2 0 0 9}$ & $\mathbf{2 0 1 0}$ & $\mathbf{2 0 1 1}$ & $\mathbf{2 0 1 2}$ & $\mathbf{2 0 1 3}$ & $\mathbf{2 0 1 4}$ \\
\hline DEU & 2 & 2 & 2 & 3 & 3 & 3 \\
\hline FRA & 3 & 4 & 4 & 4 & 4 & 4 \\
\hline ITA & 7 & 7 & 7 & 8 & 8 & 8 \\
\hline POL & 9 & 10 & 10 & 14 & 15 & 15 \\
\hline
\end{tabular}

Tab. 11 lists the destinations whose performance goes worse through the given years. The Tab. 11 indicates that Germany (DEU), France (FRA) and Italy (ITA) fell one rank below in the period from 2009 to 2014. However, one should always take into account that though these destinations are in this list with their falling performance in the period from 2009 to 2014, they still keep an important place in the number of tourists they attract and in the rating order they occupy in the competitive world of tourism. The place of Poland is also striking in this table. The tourism activities of this destination is getting worse every other year from 2009 to 2014. It was in the 9th order in 2009 and went gradually down to the 15th place in the year 2014. However, the case is also an outstanding one because the data from the four factors prove that all factors show improvement in this destination from 2009 till 2014 but the rise is below the other countries and it caused this destination to go back every other year.

A survey to the related literature may hold some studies with the TOPSIS method. The distinction between those studies and this study is the fact that this study yields a result of wide range (15 important destinations of the world consisting of $70 \%$ of the world tourism) converting the tourism activities such as international tourism expenditures, international tourism receipts, the number of inbound and the number of outbound tourists into one single score by means of the TOPSIS method. The studies made by means of TOPSIS are mainly focused on local or regional competition of the countries or organizations. Rather than local or regional tourism, this study focuses on global dimension of tourism, overlooking the world tourism from a different global angle to see the whole.

Few studies can be found in the related literature where the factors such as the tourism activities such as international tourism expenditures, international tourism receipts, the number of inbound and the number of outbound tourists are processed with the TOPSISmethod, which makes this study a more meaningful one. Another aspect of this study is that it uses the data from as recent as 2014 .

\section{SOURCES}

Charnes, A., W., Cooper, W \& Rhodes, E., “ Measuring The Efficiency Of Decision Making Units", European Journal Operational Research, (1978), Vol. 2, 429-444.

Demireli, E., “Topsis Çok Kriterli Karar Verme Sistemi: Türkiye'deki Kamu Bankaları Üzerine Bir Uygulama”, Journal of Entrepreneurship and Development, 5(1), 2010, ss. 101-112.

Deng, H.,Yeh, C.H.\& Willıs,R.J., "Inter Company Comparison Using Modified TOPSIS With Objective Weights", Journal of Computers \& Operations Research, Vol.27, Issue 10, September 2000, ss. 963-973. 
Dumanoğlu, S. \& Ergül, N. 'İmkb’de İşlem Gören Teknoloji Şirketlerinin Mali Performans Ölçümü”, Muhasebe ve Finansman Dergisi, 2010, 48, 101-111.

Eleren, A. \& M. Karagül, “ 1986 -2006 Türkiye Ekonomisinin Performans Değerlendirmesi”,University of Celal Bayar, İ.İ.B.F. Yönetim ve Ekonomi Dergisi, 2008, 15 (1), 1-14.

Feng, C.M. \& Wang, R.T., "Performance Evaluation For Airlines Including The Consideration of Financial Ratios", Journal of Air Transport Management, Vol. 6, 2000, Ss. 133-142.

Huang, J. H.,\& Peng, K. H. (2012). Fuzzy Rasch model in TOPSIS: A new approach for generating fuzzy numbers to assess the competitiveness of the tourism industries in Asian countries. Tourism Management, 33(2), 456-465.

Hwang, C.L \& K. Yoon, K. , Multiple Attribute Decision Making, SpringerVerlag, Berlin, 1981.

Karimi, M. S., Yusop, Z., \& Law, S. H. (2010). Location decision for foreign direct investment in ASEAN countries: A TOPSIS approach. International Research Journal of Finance and Economics, 36(1), 196-207.

LI,H. \& Qing-Sheng, X. , “Application of TOPSIS in the Bidding Evaluation of Manufacturing Enterprises," 5 th. International Conference on Engineering \& Digital Enterprise Technology, $16^{\text {th }}-18^{\text {th }}$ August, Guiyang, 2006, China, 184-188.

LUO, W. B., WANG, Y. J., WU, Y. Z. \& WU, Z. B. (2008). A Study on the Evaluation of Coordination between Urban Tourism and Urban Development Based on the Method of TOPSIS_A Case Study of Hangzhou [J]. Tourism Tribune, 12, 009.

Mangir, F. \& Erdogan, S. (2011). Comparison of Economic Performance Among Six Countries In Global Financial Crisis: The Application Of Fuzzy TOPSIS Method. Economics, Management and Financial Markets, 6(2), 122-136.

Mohamad, D. \& Jamil, R. M. (2012). A Preference Analysis Model for Selecting Tourist Destinations based on Motivational Factors: A Case Study in Kedah, Malaysia. Procedia-Social and Behavioral Sciences, 65, 20-25.

Shamai, A. \& Mosivand, J. (2011). Classification of cities of Isfahan province in view point of tourism infrastructure by using TOPSIS and AHP models. Journal of UrbanRegional Studies and Research, 3(10), 23-40.

Shih, H.S., Shyur, H.J. \& Lee, E.S. "An extension of TOPSIS For Group Decision Making", Mathematical and Computer Modelling, Vol. 45, No 7-8, April 2007, ss. 801-813.

The World Bank (2015), Data, International Tourism Statistics , http://www.worldbank.org/ 
UNWTO ( World Tourism Organization), (2015), http://www2.unwto.org/

Urfalığlu, F. \& Genç, T. (2013). Çok Kriterli Karar Verme Teknikleri İle Türkiye'nin Ekonomik Performansının Avrupa Birliği Üye Ülkeleri İle Karşılaştıılması . (Turkish). Marmara University Journal Of Economic \& Administrative Sciences, 35(2), 329-359. doi:10.14780/iibdergi.201324469

Uygurtürk, H. \& Korkmaz, T. , "Finansal Performansın TOPSIS Çok Kriterli Karar Verme Yöntemi İle Belirlenmesi: Ana Metal Sanayi İşletmeleri Üzerine Bir Uygulama" Univesity of Eskişehir Osmangazi, İiBF Dergisi, Ekim 2012, 7(2), ss. 95-115.

Yeh, C,H., "A problem Based Selection Of Multi-Attribute Decision-Making Methods", Journal of International Transactions in Operational Research, Vol.9, 2002, ss. 169-181.

Yükçü, S. \& Atağan, G. , "TOPSIS Yöntemine Göre Performans Değerleme”, Journal of Accounting and Finance, january, 2010, ss.28-36.

Zhang, H. \& Zhang, Y. (2010). Comparative Analysis On Regional Compettiveness Of Tourism Resources Based On Weighted TOPSIS Method - A Case Study Of The Yangtze River Delta .Resources and Environment in the Yangtze Basin, 19(5), 500-505. 